Dunamis: Jurnal Teologi dan Pendidikan Kristiani

Volume 4, Nomor 1 (Oktober 2019)

ISSN 2541-3937 (print), 2541-3945 (online)

http://www.sttintheos.ac.id/e-journal/index.php/dunamis

\title{
Metafora "Meja Makan" sebagai Upaya Membangun Toleransi di Tengah Kehidupan Masyarakat Indonesia Yang Majemuk
}

\author{
Mariani Harmadi \\ Program Studi Magister Pendidikan Agama Kristen Sekolah Tinggi Theologia Baptis \\ Indonesia \\ marianiharmadi88@gmail.com
}

\begin{abstract}
The plurality of Indonesian society became a potential conflict that endangers the life of the nation and state if it was not managed properly. For this reason tolerance became an important attitude in living together. This article aimed to review efforts in buliding tolerance in the life of a pluralistic society. Through literature review it was descripted that tolerance could be built through a philosophy rooted in the local culture of Indonesian society. The "dining table" metaphor was an effective strategy in realizing tolerance in a pluralistic society.
\end{abstract}

Keywords: pluralistic society; tolerance; dinning table; dialogue

\begin{abstract}
Abstrak
Kemajemukan masyarakat Indonesia menjadi suatu potensi konflik yang membahayakan keberlangsungan kehidupan berbangsa dan bernegara apabila tidak dikelola dengan baik. Untuk itu maka toleransi menjadi suatu sikap yang penting dalam kehidupan bersama. Artikel ini bertujuan untuk mengulas upaya membangun toleransi dalam kehidupan masyarakat yang majemuk. Melalui kajian pustaka tergambarkan bahwa toleransi dapat dibangun melalui falsafah yang berakar dari budaya masyarakat Indonesia. Metafora "meja makan" menjadi strategi yang efektif dalam mewujudkan tolerasi di tengah masyarakat yang majemuk.
\end{abstract}

Kata Kunci: masyarakat yang majemuk: toleransi; meja makan; dialog 


\section{PENDAHULUAN}

Perkembangan teknologi pada era revolusi industri 4.0 belum terlampaui sepenuhnya, kini Jepang sudah memasuki era revolusi industri 5.0 yang akan semakin memfasilitasi tuntutan kemajuan teknologi yang sangat masif. Jika perkembangan teknologi tidak diimbangi dengan kesiapan mental para sumber daya manusia atau masyarakat pengguna fasilitas, maka akan menimbulkan bencana kemanusiaan.

Kekuatiran akan hal ini telah terbukti dengan dampak kejahatan di tengah masyarakat yang disinyalir akibat informasi dari gawai yang mengadu domba pihakpihak yang sedang bersaing dalam pemilu, juga sebelumnya berita yang marak tentang perekrutan kelompok jihad dengan teknik perakitan bom disertai kegunaannya untuk berjihad demi menegakkan keadilan dan perjuangan mencapai cita-cita mulia yang semu. Selain juga konsumsi tayangan orang dewasa yang ditawarkan tanpa memilah usia dan cukup dengan menyentuh layar monitor saja, sehingga berdampak pada kerusakan moral anak-anak dan remaja akibat tontonan yang mempengaruhi gejolak hormon sebelum memasuki masa kesiapan menginjak dewasa secara fisik dan psikis. Juga dampak yang lebih jauh yaitu prostitusi dan perdagangan manusia termasuk penjualan organ tubuh manusia.

Pada era dunia tanpa batas ini Yewangoe mensinyalir bahwa paham, wawasan dan rasa kebangsaan Indonesia sedang berada pada dua tarikan arus, yaitu globalisasi dan primordialisme yang dapat membuat seseorang terbawa begitu saja oleh proses sejarah yang sedang mengalir deras sehingga pada suatu saat kehilangan identitasnya. ${ }^{1}$ Karena itu, orang merasa terancam dengan proses globalisasi yang dapat menggoyahkan identitas kebangsaan, sehingga untuk pertahanan dirinya, menyusun suatu mekanisme yang berlebihlebihan, antara lain dengan usaha mencari perlindungan pada kelompok suku, ras, agama dan golongannya sendiri.

Namun yang lebih berbahaya adalah anggapan bahwa suku, ras, agama dan golongan lain merupakan ancaman terhadap dirinya, sehingga sikap primordialisme ini menimbulkan permusuhan yang membabi buta terhadap kelompok lain yang berbeda suku, ras, agama dan golongan tanpa mempertimbangkan sejarah kehidupan bersama yang telah berlangsung sebelumnya dalam membangun negeri ini. Hal ini nampak dari dibangunnya pengkotak-kotakkan antara pribumi dan

\footnotetext{
${ }^{1}$ Andreas A. Yewangoe, Agama Dan Kerukunan (Jakarta: BPK Gunung Mulia, 2016), 15.
} 
non-pri, mayoritas dan minoritas, penduduk asli dan pendatang, serta mempertajam perbedaan lain dengan pembenaran berdasarkan keyakinan dan ideologinya sendiri.

Sikap toleransi yang selama ini merekatkan hubungan masyarakat dengan saling menghormati, saling bertenggang rasa, bergotong royong, bermusyawarah dalam mengatasi masalah lingkungan, kerja bakti dan ronda jaga malam sebagai ajang bertegur sapa dan mempererat tali kekerabatan menjadi sirna karena dimunculkannya prasangka terhadap satu dengan yang lain. Bhineka Tunggal Ika sebagai falsafah yang diwariskan secara turun temurun dari generasi ke generasi mulai diragukan efektivitasnya bagi kehidupan yang membangun kekuatan dan kesatuan bangsa ini.

Tujuan artikel ini adalah untuk mendeskripsikan upaya membangun toleransi yang berakar dari budaya bangsa Indonesia sendiri namun juga sekaligus tidak bertentangan dengan prinsip-prinsip yang diajarkan dalam Alkitab. Dalam upaya membangun toleransi tersebut, penulis menitikberatkan pada metafora "meja makan" sebagai upaya membangun dialog

\footnotetext{
2 Benny Susetyo, "Membumikan Pancasila: Aktualisasi Nilai Dan Pembudayaan Karakter," in Revitalisasi Indonesia Melalui Identitas
}

untuk mewujudkan toleransi dalam masyarakat majemuk.

\section{METODE PENELITIAN}

Metode penelitian yang digunakan dalam artikel ini adalah melalui studi kepustakaan dari sudut pandang bidang teologi praktika yang bertolak dari praksis atau pengalaman yang direfleksikan, yaitu pengalaman dalam konteks historis dan sosial yang dihayati dengan langkah penafsiran makna berdasarkan kajian sosiologi agama, masyarakat dan komunikasi. Sehingga dari pemeriksaan setiap penafsiran mengenai pengalaman tersebut diperoleh pengakuan normatif sebagai suatu isu yang berkembang juga pada masyarakat umumnya dan bukan sebagai pengalaman pribadi yang subjektif semata.

\section{HASIL DAN PEMBAHASAN}

Sikap intoleran biasanya ditandai dengan sikap arogan, superior, rasial, yang bertentangan dengan semangat membangun "kesederajatan/ persamaan dalam perbedaan."2 Sebagai wujud kekeluargaan bangsa Indonesia yang plural ini dalam mengamalkan sila ke-4 Pancasila, Benny Susetyo mencirikannya dengan empat hal,

Kemajemukan Berdasarkan Pancasila (Jakarta: Universitas Kristen Indonesia, 2018), 20. 
yaitu: (1) harus didasarkan pada asas rasionalitas dan keadilan, bukan hanya berdasarkan subjektivitas ideologis dan kepentingan; (2) didedikasikan bagi kepentingan banyak orang, bukan demi kepentingan perseorangan atau golongan; (3) berorientasi jauh ke depan, bukan demi kepentingan jangka pendek melalui akomodasi transaksional yang bersifat destruktif (toleransi negatif); (4) bersifat imparsial dengan melibatkan dan mempertimbangkan pendapat semua pihak (minoratis terkecil sekalipun) secara inklusif, yang dapat menangkal dikte-dikte minoritas elite penguasa dan pengusaha serta klaim-klaim mayoritas. Usaha dialog antar pemuka agama yang didasarkan pada semangat toleransi merupakan usaha mencairkan ketegangan atau meruntuhkan tembok prasangka yang diakhiri dengan "Shalom" tanpa menyisakan kemarahan atau dendam dari pihak mana pun termasuk pihak yang menjadi korban kekerasan.

Suhu politik yang kian menghangat dan berpotensi merebaknya konflik juga sangat mudah dipicu oleh adanya berita hoaks dari penggunaan gawai. Situasi ini merupakan salah satu benih timbulnya bencana kemanusiaan yang tidak perlu

\footnotetext{
${ }^{3}$ George Royke Deksino, "Membangun Ketahanan Nasional Yang Berkelanjutan Dalam Konteks Kemajemukan Bangsa Indonesia," in Revitalisasi
}

terjadi jika sesegera mungkin dilakukan dialog antar pihak yang berkonflik dengan dilandasi oleh solidaritas dan toleransi yang tinggi, serta menjauhkan diri dari rasa superioritas, chauvinitas dan diskriminasi berdasarkan SARA. $^{3}$ Media sosial yang merupakan salah satu bentuk kecanggihan teknologi pada era revolusi industri 4.0 ini memberi kemudahan bagi pertukaran dan penyebaran informasi sekaligus menjadi ancaman yang dapat menimbulkan kegaduhan ketika diisi dengan kebohongan, ujaran kebencian, dan fitnah sehingga pengguna fasilitas ini perlu meningkatkan kewaspadaan, bijak, cerdas meneliti sejauh mana kebenaran berita yang diterima sesuai ajaran Paulus dalam 1 Tesalonika 5:21 "Ujilah segala sesuatu dan peganglah yang baik."

Undang-undang Nomor 7 Tahun 2012 tentang Penanganan Konflik Sosial menyebutkan bahwa kepolisian memegang peranan penting sebagai alat negara dalam memelihara keamanan dan ketertiban masyarakat, menegakkan hukum, serta memberikan perlindungan, pengayoman, dan pelayanan. Namun usaha penanganan konflik sosial perlu disertai keterlibatan secara aktif dari setiap individu, kelompok,

Indonesia Melalui Identitas Kemajemukan Berdasarkan Pancasila (Jakarta: Universitas Kristen Indonesia, 2018), 75. 
dan masyarakat dengan berperilaku sesuai norma yang disepakati sehingga terwujud pertahanan yang kuat terhadap hoaks sebagai salah satu penyulut konflik sosial sekarang ini. Selain juga secara periodik masyarakat mulai dari kelompok kecil yang heterogen membentuk wadah interaksi untuk berdialog dalam menyelesaikan masalah yang terjadi di lingkungan setempat guna mengantisipasi meluasnya persoalan ke wilayah lain.

Gerakan moral bagi pembaruan, perbaikan, bahkan menggoyang kemapanan (status quo) merupakan salah satu agenda pelayanan Yesus (Luk. 2:18-19) sebagai warna negara dari suatu pemerintahan di muka bumi ini seperti panggilan yang sama kepada nabi Yesaya (Yes 61:1-2) mendasari tugas pelayanan-Nya demi "kepenuhan hidup bagi semua,"4 dimana pengikut Kristus pun sebagai warga negara terhisab dalam panggilan ini untuk menyuarakan kebenaran berdasarkan keyakinan iman terhadap tanggung jawab dalam cara yang mencakup dialog dan rekonsiliasi. Peran PAK dalam masyarakat majemuk melalui keluarga, gereja, sekolah atau lembaga rohani lainnya dalam mempersiapkan generasi penerus bangsa merupakan bagian

\footnotetext{
${ }^{4}$ Hope S Antone, Pendidikan Kristiani Kontekstual - Mempertimbangkan Realitas Kemajemukan
}

dari pemenuhan kewajiban sebagai warga negara.

Untuk itu langkah-langkah bagi merealisasikan toleransi sebagai benih dialog yang diusulkan Antone yang disebut sebagai "kerangka kerja meja makan", pertama harus didasarkan pada pemahaman dan proses analisis konteks bukan sebatas ruang geografis melainkan ruang sosial budaya yang dinamis, suatu ruang kemanusiaan dan sejarah. Warisan budaya bangsa di nusantara ini adalah gotong royong, ritual yang biasa diawali dan diisi dengan makan bersama yang merupakan media bagi terjalinnya dialog. ${ }^{5}$ Kerangka kerja meja makan suatu strategi yang cocok digunakan di kalangan masyarakat agraris yang akrab dengan hasil pangan seperti halnya yang terwujud pada pesta panen yang mempersatukan warga untuk makan bersama dari hasil panen yang diperolehnya dengan sukacita dimana seremonial ini selain berujud pengucapan syukur kepada Sang Pemberi hidup (hubungan vertikal) juga untuk melumerkan kebekuankebekuan yang terjadi di antara sesama warga (hubungan horizontal).

Dalam Pendidikan Agama (Jakarta: BPK Gunung Mulia, 2012), 147.

5 Ibid, 145-146. 


\section{Menciptakan Shalom melalui Dialog}

Sesungguhnya aset budaya gotong royong yang diwariskan para leluhur sejalan dengan misi keselamatan bagi manusia seutuhnya sesuai dengan arti yang terkandung dalam istilah "shalom" (Perjanjian Lama) berasal dari akar kata "salam" dan "selamat" kemudian diterjemahkan sebagai keselamatan, damai sejahtera, sehat, aman, tenteram dll. ${ }^{6}$ Strategi yang dapat dilakukan untuk mewujudkan shalom tersebut sebagai berikut: pertama, sesuai dengan Ulangan 20:10, "Apabila engkau mendekati suatu kota untuk berperang melawannya, maka haruslah engkau menawarkan perdamaian kepadanya," artinya ada usaha berdialog untuk mencari jalan keluar sebelum mengambil keputusan untuk berperang. Kedua, Yesaya 33:7, "Lihat, orang-orang Ariel menjerit di jalan, utusan-utusan yang mencari damai menangis dengan pedih," artinya ada kepedulian dan empati terhadap kesusahan yang dialami sesama manusia mana pun.

Ketiga, Yesaya 55:12, "Sungguh, kamu akan berangkat dengan sukacita dan akan dihantarkan dengan damai; gununggunung serta bukit-bukit akan bergembira dan bersorak-sorai di depanmu, dan segala pohon-pohonan di padang akan bertepuk tangan," artinya usaha dialog yang dilandasi dengan empati pasti akan berhasil meredam perang yang direncanakan sekalipun. Keempat, 1 Raja-raja 5:12, "Mengenai rumah yang sedang kaudirikan ini, jika engkau hidup menurut segala ketetapan-Ku dan melakukan segala peraturan-Ku dan tetap mengikuti segala perintah-Ku dan tidak menyimpang dari padanya, maka Aku akan menepati janji-Ku kepadamu yang telah Kufirmankan kepada Daud, ayahmu," artinya Allah sendiri tidak berpangku tangan terhadap usaha-usaha menciptakan shalom bagi umat-Nya melainkan akan mewujudkan janji-Nya sebagai upah dari suatu ketaatan.

\section{Strategi Dialog}

Kata "dialog" berasal dari kata Yunani "dia-logos" artinya bicara antara dua pihak, atau "dwiwicara" dimana percakapan antara dua orang (atau lebih) dalam mana diadakan pertukaran nilai yang dimiliki masing-masing pihak yang bertujuan untuk sesuatu yang positif, yaitu memberi informasi dan nilai-nilai yang dimiliki, lalu membantu pihak lain mengambil keputusan yang dapat

\footnotetext{
${ }^{6}$ A.A. Sitompul, Manusia Dan Budaya: Teologi Antropologi (Jakarta: BPK Gunung Mulia, 2000), 185.
} 
dipertanggungjawabkan. ${ }^{7} \quad$ Keterlibatan 'saling' beberapa pihak dalam dialog menimbulkan persilangan yang pada awalnya mungkin agak canggung, tetapi jika secara terus menerus dilakukan niscaya akan ada multi jalinan komunikasi yang efektif untuk menghasilkan informasi yang dipersetujui berbagai pihak. Dengan demikian pertukaran dan informasi yang terjadi sekaligus akan meningkatkan kedekatan hubungan antara pihak-pihak yang terlibat. Seperti halnya yang terjadi dengan pengalaman Tuhan Yesus dalam percakapan dengan Nikodemus (Yoh. 3:121) juga dengan perempuan Samaria (Yoh. 4:1-42) bahkan dengan perempuan SiroFenesia (Mrk. 7:24-30) yang jika berhenti pada tahap saling menyapa di permukaan saja, pasti tidak akan ada pengalaman yang bermakna dan mencapai sasaran yang mewujudkan shalom.

Dialog merupakan salah satu momentum proses sosial, suatu proses berpola yang selalu terjadi dalam masyarakat yang terarah menjadi wadah kerjasama dari pihak-pihak yang berkepentingan. ${ }^{8}$ Dalam kerangka itu dialog merupakan bagian dari proses sosial yang assosiatif, yang bertolak dari situasi kekosongan (vacum) dan kesepian, atau

\footnotetext{
${ }^{7}$ D Hendropuspito, Sosiologi Agama (Yogyakarta: Penerbit Kanisius, 1983), 172-173.
}

dari situasi konflik yang dialami pihakpihak yang berkepentingan. Dengan demikian dialog dapat merupakan jalan keluar untuk mengatasi keadaan bermusuhan dan menciptakan modus vivendi yang damai dan kooperatif. Pengalaman Yosua dalam menjalin persahabatan dengan penduduk negeri Gibeon dan mengikat perjanjian dengan mereka, walaupun motivasi yang digunakan oleh penduduk Gibeon itu buruk tetapi strategi dialog yang digunakannya efektif mencapai tujuan (Yos. 9:1-15).

Salah satu pokok bahasan dalam dialog yang efektif adalah dengan menjawab tantangan baru antara lain ketidakadilan, terorisme international, kemiskinan terstruktural, sekularisme kiri, bencana alam nasional. ${ }^{9}$ Karena masalah tersebut tidak mungkin diatasi oleh satu komunitas tertentu saja, tetapi membutuhkan konsolidasi dari segala kekuatan baik moral, spiritual maupun material semua umat beragama. Situasi ketegangan dan stress yang dialami bersama memang dapat menjadi alat untuk merekatkan hubungan pihak-pihak yang sebelumnya bertikai atau belum terjembatani untuk berinteraksi. Seperti dalam pengalaman pelayanan untuk

\footnotetext{
${ }^{8}$ Ibid, 172-173.

${ }^{9}$ Ibid.
} 
mengakrabkan remaja di suatu desa yang sebelumnya mudah terpicu untuk konflik, maka dibentuklah satu tim sepakbola dan mencari tim lawan untuk bertanding, maka selama proses latihan terjadi interaksi antar individu dengan saling memotivasi hingga akhirnya terbentuk tim yang solid dan siap bertanding untuk menang. Sejak saat itu pertikaian yang sering terjadi mulai berangsur-angsur cair bahkan mereka menjadi tim yang saling mendukung kekuatan anggota timnya dan melindungi kekurangan anggota tim lainnya. Jika usaha ini mulai dirintis dalam skala kecil, tidak mustahil benih ini akan berkembang dan membudaya dalam masyarakat sehingga shalom terwujud di seluruh nusantara sebagai aset untuk diwariskan kepada generasi selanjutnya secara turun temurun.

Mulder, tokoh yang berpandangan positif tentang agama-agama dan cukup dikenal di Indonesia banyak bergumul dengan persoalan dialog berpendapat bahwa kerukunan umat beragama menjadi keprihatinannya yang utama. ${ }^{10}$ Ia menyesal bahwa di dalam sejarah, agama-agama yang seharusnya membawa perdamaian bagi setiap orang telah berubah menjadi pembawa malapetaka. Perang-perang yang ikut dimotivasi agama merupakan catatan hitam sejarah yang tidak terhapuskan. Namun ia berkeyakinan bahwa masih ada harapan bagi orang-orang yang mempunyai latar belakang agama yang berbeda untuk saling mendengarkan dan saling menghargai dengan dasar: pertama, agama Kristen mengakui bahwa semua manusia diciptakan menurut gambar dan rupa Tuhan (Kej. 1:26; 5:1). Tuhan memberkati mereka dan memberikan nama "manusia" kepada mereka (Kej 5:2). Karena itu, semua manusia adalah sesama manusia. Kedua, Tuhan tidak hanya menciptakan semua manusia, tetapi juga memperhatikan, mempedulikan dan memeliharanya (Kis. 17:25-26). Tuhan memberikan hidup dan napas kepada semua orang.

Ketiga, Tuhan juga menyatakan diri-Nya kepada mereka (Kis. 14:16-17) melalui berbagai kebajikan seperti menurunkan hujan, memberikan musimmusim subur, memuaskan hati dengan makanan dan kegembiraan. Keempat, Tuhan memperhatikan semua manusia berdasarkan kasih karunia-Nya yang tidak terbatas hanya kepada bangsa Israel atau umat pilihan-Nya, melainkan meliputi semua manusia. Kalau seorang Kristen bertemu dengan seorang yang beragama lain, maka ia bukan bertemu dengan

\footnotetext{
10 Yewangoe, Agama Dan Kerukunan, 74-76.
} 
seorang lawan atau musuh, tetapi berjumpa dengan saudara yang juga dikasihi Allah. Seperti halnya yang dilakukan oleh orang Samaria yang merawat korban kejahatan yang teraniaya dan membutuhkan kasih dan pertolongan.

\section{Toleransi dalam Kisah Alkitab}

Tuhan Yesus mengajarkan sikap toleransi melalui peristiwa yang dicatat Markus 9:30-40 dan Lukas 9:49-50 ketika ada orang-orang yang bukan pengikut Yesus melakukan mujizat dengan mengusir setan, Tuhan Yesus menegaskan "barangsiapa tidak melawan kamu, ia ada di pihak kamu" (Luk. 9:50); "Barangsiapa tidak melawan kita, ia ada di pihak kita" (Mrk. 9: 40). Sikap eksklusif mengganggap bahwa orang yang di luar atau tidak termasuk dalam kelompok adalah orang yang berbeda atau yang lebih ekstrem adalah lawan atau musuh. Paulus dalam Roma 14:1-23 mengajarkan sikap toleransi terhadap praktek kehidupan sehari-hari menyangkut makanan, hari tertentu, berdiri atau jatuh, hidup atau mati, demi mencapai tujuan hidup yang sesungguhnya, "Sebab itu marilah kita mengejar apa yang mendatangkan damai sejahtera dan yang berguna untuk saling membangun" (Rm. 14:19). Juga 1 Korintus 10:28-32 tentang persembahan berhala tetapi dengan tujuan akhir "Sama seperti aku juga berusaha menyenangkan hati semua orang dalam segala hal, bukan untuk kepentingan diriku, tetapi untuk kepentingan orang banyak, supaya mereka beroleh selamat (1 Kor. $10: 33)$.

Sebaliknya, sikap intoleran dapat dilihat contohnya pada Yosua. Yosua bin Nun yang sejak mudanya menjadi abdi Musa juga bersikap intoleran terhadap Eldad dan Medad sebagai orang yang tidak diperhitungkan dalam tujuh puluh tua-tua yang mengalami kepenuhan Roh seperti nabi di tempat perkemahan, hingga Yosua minta kepada Musa untuk mencegah mereka (Bil. 11:24-28). Demikian juga dengan sikap intoleransi Yunus yang menjadi marah atas pertobatan bangsa Niniwe kendati itu hasil pelayanannya, karena menurutnya bangsa ini layak dimusnahkan daripada mereka dibebaskan dari hukuman dosa (Yun. 3:10; 4:4).

Sikap intoleran orang Yahudi juga dialami oleh murid-murid Yesus dalam sejarah perkembangan gereja mula-mula yang dicatat Kisah Para Rasul 4:1-3; 15-21; 17:13. Ketika Petrus dan Yohanes sedang berbicara kepada orang banyak, mereka tiba-tiba didatangi imam-imam dan kepala pengawal Bait Allah serta orang-orang Saduki. Orang-orang itu sangat marah karena mereka mengajar orang banyak dan 
memberitakan, bahwa dalam Yesus ada kebangkitan dari antara orang mati. Mereka ditangkap dan diserahkan ke dalam tahanan sampai keesokan harinya, karena hari telah malam.

Umat Kristiani sebagai kaum minoritas tidak boleh menyerah kepada situasi intoleransi. Bahkan respon terhadap sikap permusuhan dari orang Samaria, Tuhan Yesus tetap berusaha mencari kesempatan untuk berinteraksi dengan mereka yang dituturkan pada Luk 9:51-56. Penolakan orang Samaria tidak menimbulkan kebencian pada diri Tuhan Yesus sehingga tidak mengijinkan muridmurid-Nya membalas dengan hukuman bahkan Tuhan Yesus mengajarkan untuk mengasihi orang yang memusuhi, dengan perumpamaan "orang Samaria yang baik hati” (Luk. 10:29-37). Tuhan Yesus mengajarkan sikap toleransi dengan menghancurkan prasangka terhadap pihak yang mungkin dianggap "musuh" atau "bermusuhan" seperti yang dituturkan dalam peristiwa penyembuhan 10 orang yang sakit kusta, yang ternyata berbalik untuk mengucapkan terima kasih hanya 1 orang saja dan dia itu adalah orang Samaria (Luk. 17:11-18).

\footnotetext{
${ }^{11}$ Ibid, 155

${ }^{12}$ Ibid, 156.
}

\section{Toleransi sebagai Benih Dialog}

Dalam konteks Indonesia, membangun persatuan dan kesatuan adalah "Perjanjian luhur" bangsa Indonesia (Yewangoe, 2016:155) yang mengisyaratkan bahwa tidak ada warga negara kelas satu dan warga negara kelas dua. ${ }^{11}$ Kita membangun kebersamaan secara bersama-sama. Itulah sebenarnya hakekat masyarakat Pancasila, di mana sikap menahan diri dan tenggang rasa menjadi ciri-ciri utamanya. ${ }^{12}$ Tercabiknya Perjanjian Luhur dengan cerminan sikap intoleransi dan fanatisme sebagaimana dirumuskan oleh Bierstedt demikian, "Kalau saudara berkuasa adalah kewajiban saudara untuk mentolerir saya karena saya benar; tetapi kalau saya berkuasa adalah kewajiban saya untuk mengejar saudara karena saudara salah."13 Hal ini disimpulkan sebagai pedoman emas (Hendropuspito,156) bahwa sikap toleran ialah kesediaan untuk menerima orang lain walaupun hal itu sepertinya sulit masuk dalam benak seorang fanatikus. ${ }^{14}$

Pandangan Baidhawy melengkapi pemahaman tentang toleransi adalah "kesiapan dan kemampuan batin untuk kerasan bersama orang lain yang berbeda secara hakiki meskipun terdapat konflik

\footnotetext{
${ }^{13}$ Hendropuspito, Sosiologi Agama, 155.

${ }^{14}$ Ibid, 156.
} 
dengan pemahaman anda tentang apa yang baik dan jalan hidup yang layak."15 Toleransi tidak diragukan lagi merupakan salah satu kebajikan fundamental demokrasi, namun ia memiliki kekuatan ambivalen yang termanifestasi dalam dua bentuk: bentuk solid dan bentuk dekoratif. Menjadi toleran adalah membolehkan orang lain menjadi diri mereka sendiri, menghargai orang lain, asal-usul dan latar belakang mereka dan bukan keinginan untuk mempengaruhi mereka agar mengikuti ide kita dan demi kemajuan tertentu.

Toleransi mengundang dialog untuk mengkomunikasikan dan menjelaskan perbedaan serta adanya saling pengakuan. Inilah toleransi dalam bentuknya yang solid. Toleransi dekoratif tidak memuat komitmen dan hanya puas dengan dirinya sendiri dan bersamaan dengan itu pasif dalam mempertemukan kebaikan milik mereka dan kita. Namun demikian, pemahaman tentang toleransi yang tidak diwujudnyatakan dalam kehidupan sosial seperti melihat cermin dan melupakannya. Untuk itu, kehidupan berkelompok yang dinamis dapat menjadi pisau yang semakin menajamkan toleransi dalam bentuk yang

\footnotetext{
${ }^{15}$ Zakiyuddin Baidhawy, Pendidikan Agama Berwawasan Multikultural (Jakarta: Penerbit Erlangga, 2005), 79.
}

solid bukan hanya sekedar toleransi yang dekoratif.

Suatu cerita tentang "Situasi Kapal yang Tenggelam"16 dapat menjadi contoh bagi toleransi. Pada suatu malam di musim panas. Tujuh orang berpegangan erat pada sebuah kapal yang perlahan-lahan tenggelam di laut tropis hitam. Mereka tidak sendiri. Seekor ikan paus berenang di bawah mereka, dan mungkin dengan segera akan bertambah jumlahnya. Dengan menahan takut yang amat hebat, ketujuh orang tersebut menghadapi pilihan yang sulit. Jika mereka mendayung bersamasama, mereka mungkin dapat melawan ombak yang mengerikan dan gelombang akan membawa mereka ke tepi laut dan mereka semua selamat; jika mereka tetap bersama-sama mereka punya kesempatan yang sama untuk bertahan atau tenggelam. Jika mereka berpencar, masing-masing pergi sendiri-sendiri, satu atau dua orang perenang yang lebih kuat mungkin dapat selamat, tapi sebagian besar akan tenggelam atau dimangsa oleh paus-paus. Kapal ini serupa gambaran wadah suatu kelompok pelbagai orang dengan kondisi yang berbeda masing-masing dengan kekuatan dan kelemahannya, tetapi menuju arah yang

\footnotetext{
${ }^{16}$ David W. Johnson and Frank P. Johnson, Dinamika Kelompok: Teori Dan Keterampilan, 9th ed. (Jakarta: PT Indeks, 2012), 26.
} 
sama dengan selamat. Bagaimana cara kelompok ini selamat di tempat tujuan? Dialog dan toleransi merupakan salah satu cara yang efektif menemukan solusi bagi keselamatan semua penumpang dalam kapal.

\section{KESIMPULAN}

Dialog dapat menyemaikan benih toleransi yang berkembang dan sebaliknya toleransi merupakan benih yang menumbuhkan semangat berdialog. Metafora "meja makan" yang memelihara budaya makan bersama dan bersifat komunal merupakan salah satu cara membuat mata rantai satu dan lainnya terjalin erat dan kuat. Strategi "meja makan" bagi bangsa timur yang menghargai beras sebagai primadona dari perlambang kesuburan dan kedaulatan Sang Pencipta yang Pemelihara sangat efektif untuk menjadi alat diplomasi untuk menyelesaikan konflik. Peribahasa 'dari mata turun ke hati, dari mulut turun ke perut' mencerminkan figur bangsa kita yang mana hati dan perut masing-masing berfungsi mengendalikan emosi yang mampur mencairkan suasana yang kaku sekalipun. Obrolan sebagai selingan pada waktu makan dapat melepaskan hal-hal yang mungkin sebelumnya mengganggu hubungan seseorang dengan orang lainnya, namun setelah berada dalam suatu meja dengan menu yang sama baik dengan cara makan modern atau yang traditional, maka pencairan suasana akan terjadi sehingga benih toleransi kembali dapat tersemaikan.

\section{DAFTAR PUSTAKA}

Antone, Hope S. Pendidikan Kristiani Kontekstual-Mempertimbangkan Realitas Kemajemukan Dalam Pendidikan Agama. Jakarta: BPK Gunung Mulia, 2012.

Baidhawy, Zakiyuddin. Pendidikan Agama Berwawasan Multikultural. Jakarta: Penerbit Erlangga, 2005.

Deksino, George Royke. "Membangun Ketahanan Nasional Yang Berkelanjutan Dalam Konteks Kemajemukan Bangsa Indonesia.” In Revitalisasi Indonesia Melalui Identitas Kemajemukan Berdasarkan Pancasila. Jakarta: Universitas Kristen Indonesia, 2018.

Hendropuspito, D. Sosiologi Agama. Yogyakarta: Penerbit Kanisius, 1983.

Johnson, David W., and Frank P. Johnson. Dinamika Kelompok: Teori Dan Keterampilan. 9th ed. Jakarta: PT Indeks, 2012.

Sitompul, A.A. Manusia Dan Budaya: Teologi Antropologi. Jakarta: BPK Gunung Mulia, 2000.

Susetyo, Benny. "Membumikan Pancasila: Aktualisasi Nilai Dan Pembudayaan Karakter.” In Revitalisasi Indonesia Melalui Identitas Kemajemukan Berdasarkan Pancasila. Jakarta: Universitas Kristen Indonesia, 2018.

Yewangoe, Andreas A. Agama Dan Kerukunan. Jakarta: BPK Gunung Mulia, 2016. 
